Neice, A. A. and S. B. McRae. 2021. Mapping habitat suitability for the Eastern Black Rail throughout its Atlantic coastal range using maximum entropy (MaxEnt). Avian Conservation and Ecology 16(1):23. https://doi.org/10.5751/ACE-01919-160123

Copyright (C) 2021 by the author(s). Published here under license by the Resilience Alliance.

Research Paper

\title{
Mapping habitat suitability for the Eastern Black Rail throughout its Atlantic coastal range using maximum entropy (MaxEnt)
}

\author{
Amberly A. Neice ${ }^{1}$ and Susan B. McRae ${ }^{1}$ \\ ${ }^{1}$ Dept. of Biology, East Carolina University, Greenville, NC, USA
}

\begin{abstract}
Modeling a species' distribution can be a powerful tool for predicting the location of additional habitat. Identifying suitable habitat is of critical importance for data-deficient species of conservation concern. The Black Rail (Laterallus jamaicensis), a small marsh bird, is listed as globally endangered. We created a habitat suitability model for the eastern subspecies focusing on the Atlantic coastal plain using eBird data contributed by citizen scientists and environmental data from the Esri databank using a maximum entropy model framework. The map generated from the model indicated habitat suitability in areas known for Black Rail occupation and predicted other suitable sites. Environmental factors that best predicted Black Rail presence were flooded areas with shrub and herbaceous vegetation, proximity to water, and flat plains. These environmental associations were congruent with characteristics of high marsh, emphasizing its importance for the species. Black Rails have been found to occupy this habitat type in the coastal part of their range. Habitat association studies conducted in other parts of the species' range that focused on smaller areas and used presence/ absence survey data collected via species-targeted callback surveys identified similar habitat characteristics. Our habitat suitability model thus adds to a growing list of studies using distribution data from public databases with significant power to predict occupancy over a landscape scale. The map generated by this model will inform land management decisions and habitat restoration efforts.
\end{abstract}

\section{Cartographie du caractère propice de l'habitat chez le Râle noir de l'Est dans son aire de répartition sur la côte atlantique à l'aide de l'entropie maximale (MaxEnt)}

RÉSUMÉ. La modélisation de la répartition d'une espèce peut être un outil puissant pour prédire l'emplacement d'habitat additionnel. L'identification d'habitats propices est d'une importance capitale chez les espèces préoccupantes en matière de conservation et pour lesquelles les données sont insuffisantes. Le Râle noir (Laterallus jamaicensis), un petit oiseau de marais, est classé comme étant en danger au niveau mondial. Nous avons créé un modèle du caractère propice de l'habitat pour la sous-espèce de l'Est en nous concentrant sur la plaine côtière de l'Atlantique, à partir de données eBird fournies par des citoyens et de données environnementales provenant de la banque de données Esri, en utilisant un modèle d'entropie maximale. La carte générée à partir du modèle montre le caractère propice de l'habitat dans des zones connues pour être fréquentées par le Râle noir et prédit d'autres sites adéquats. Les facteurs environnementaux qui prédisaient le mieux la présence du Râle noir étaient les zones inondées avec une végétation arbustive et herbacée, la proximité de l'eau et les plaines sans relief. Ces associations environnementales correspondaient aux caractéristiques de hauts marais, soulignant du même coup leur importance pour l'espèce. On a constaté que le Râle noir occupait ce type d'habitat dans la partie côtière de son aire de répartition. Des études d'association d'habitats menées dans d'autres parties de l'aire de répartition de l'espèce, qui se sont concentrées sur des zones plus petites et ont utilisé des données de présence/absence recueillies au moyen de relevés réalisés avec des enregistrements sonores de l'espèce, ont identifié des caractéristiques d'habitat similaires. Notre modèle du caractère propice de l'habitat s'ajoute donc à une liste croissante d'études utilisant des données de répartition provenant de bases de données publiques et dont la capacité à prédire la présence à l'échelle du paysage est élevée. La carte générée par ce modèle permettra d'éclairer les décisions qui seront prises quant à la gestion des territoires et les activités de restauration des habitats.

Key Words: bird conservation; citizen science; ecological niche model; marshbird; Rallidae; species distribution

\section{INTRODUCTION}

The Black Rail (Laterallus jamaicensis) is a diminutive marsh bird historically found along the southeastern coastal plain of North America, with sparse populations detected in remote inland patches (Taylor and van Perlo 1998). Two North American subspecies are now recognized: the California Black Rail ( $L . j$. coturniculus) found almost exclusively in California and Arizona, and the Eastern Black Rail (L. j. jamaicensis). Historically, the range of the eastern subspecies spread broadly across the smaller dispersed inland northern eastern half of the U.S., as far north as New Jersey and as far west as eastern Colorado and Texas, with populations, but it is now principally found along the Gulf and Atlantic Coasts (Spautz et al. 2005, U.S. Fish and Wildlife Service 2018a). Both subspecies have disjunct and fragmented distributions (Richmond et al. 2008, Watts 2016). A significant loss of occupied sites in recent years has exacerbated the shrinkage of the range of the eastern subspecies (U.S. Fish and Wildlife Service 2018a).

Black Rails are now considered globally endangered (BirdLife International 2020). Conservatively, it is estimated that the Eastern Black Rail population has declined by more than $75 \%$ 
over the last decade (U.S. Fish and Wildlife Service 2018a). As of 2016, it was estimated that there were only 355-815 breeding pairs along the Atlantic coast (Watts 2016). The Eastern Black Rail was recently uplisted to Threatened status under the Federal Endangered Species Act (U.S. Fish and Wildlife Service 2018b, 2020). The Eastern Black Rail Conservation Plan cites as urgent priorities the need to identify and to expand suitable habitat for the species (Atlantic Coast Joint Venture 2020).

A better understanding of Black Rail habitat requirements is urgently needed in support of the conservation management plan. Watts (2016) compiled an extensive report on the status of the Eastern Black Rail and identified five main habitat categories where Black Rails have been detected: tidal saltmarshes, impoundments, grassy fields, freshwater wetlands, and coastal prairie. Despite their diversity, these habitats share common features of hydrology (shallow water with consistent and regular flooding) and the presence of dense, early successional vegetation (Watts 2016). In addition to these characteristics, topographic diversity has recently been associated with Black Rail occupancy (Atlantic Coast Joint Venture 2020).

Like most rails, Black Rails are secretive in nature. Their small size, cryptic appearance and behavior make them difficult to detect visually (Stuart 1920, Davidson et al. 1992). This has hindered attempts to gain information about their habitat requirements. Auditory callback survey is currently the main detection method for Black Rails (Richmond et al. 2008, Wilson et al. 2016, Tolliver et al. 2018). There is a paucity of data on the ecology and behavior of the Eastern Black Rail, but see Hand et al. (2019), for detailed breeding accounts in South Carolina.

Empirical studies in disparate parts of the range have specifically addressed habitat features associated with Black Rail occupancy during the breeding season. A radiotelemetry and nest success study in Florida concluded that Black Rails selected as nesting habitat areas of low water level formed by salt pans (Legare and Eddleman 2001). A habitat association study in South Carolina found that Black Rails were commonly found in managed impoundments and the habitat characteristics most associated with Black Rail occupancy were proximity to forest and a greater proportion of marsh surrounding the detection site (Roach and Barrett 2015). The authors inferred that the proximity to forest was not due to the presence of woody vegetation but that the birds favored the sloped landscape and shallow water associated with trees near marsh. There was also a weaker association with vegetation height above half a meter. Most recently, a study in coastal Texas identified presence of cordgrass (Spartina spp.) and intermediate marsh cover as important correlates of occupancy (Tolliver et al. 2018). This type of information informs what kind of habitat to look for but does not indicate where suitable habitat might be.

Habitat suitability modeling is a powerful way to predict sites where individuals of rare species may be found. Ecological niche modeling, species distribution modeling, and habitat suitability modeling all describe approaches that make use of large-scale remote sensing data across landscapes to determine areas that have similar features associated with locations known to be occupied by a target species (Corsi et al. 2000, Phillips et al. 2004, 2006, Pearce and Boyce 2006). Using values of biotic and abiotic variables at locations where members of a species of interest have been observed, a model is constructed that generates maps estimating the probability of finding that species at other locations based upon similar values for the same ecological variables (Corsi et al. 2000, Phillips et al. 2004, 2006, Pearce and Boyce 2006). Generated models are ideally suited to identifying habitat and predicting distributions for secretive species threatened by anthropomorphic activities (Hedley et al. 2020).

Few previous studies have attempted to use ecological niche modeling to predict current Black Rail distributions. One study evaluated habitat suitability for the California Black Rail in the Sacramento-San Joaquin Delta using a MaxEnt species distribution model with presence-only data sampled for the study from auditory surveys, with vegetation type and tidal status as the predictor variables (Tsao et al. 2015). California Black Rail presence was most often correlated with tall emergent vegetation interspersed with riparian shrubs and indicated areas of suitability that correlated with historical records (Tsao et al. 2015). A more recent study investigating Eastern Black Rails along the Texas gulf coast used a large dataset of callback surveys to determine occupancy of Black Rails across a number of contiguous and non-contiguous refuges (Haverland 2019). The model predicted rail presence mainly in high marsh habitats with minimal tidal influence and $>50 \%$ herbaceous vegetative cover. Gulf cordgrass (Spartina spartinae) was the dominant species of vegetation that correlated most highly with Black Rail occupancy in this system (Haverland 2019). A major strength of this study was that it used current presence and absence data based on extensive surveying conducted by the author and her collaborators. Detailed ground-truthing over a series of contiguous coastal refuges allowed for greater understanding of Black Rail habitat selection and identified suitable adjacent areas that are not known currently to support rails.

Black Rails are difficult to find, and occupancy data are scarce along the East Coast. One solution for expanding the dataset of Black Rail observations is utilizing citizen science data. Part of the Cornell Lab of Ornithology's citizen science initiative, eBird (eBird 2018) is a valuable source of bird presence data and has been shown to be a reasonable proxy for professionally collected data in modeling species distributions (Coxen et al. 2017, Walker and Taylor 2017). Models created from eBird data have been found to be accurate and to have strong overlap in habitat suitability scores in comparison to models created using satellite tracking data (Coxen et al. 2017) and systematically-collected bird survey data (Bradter et al. 2018). Models of 22 bird species in Ontario generated independently from either Breeding Bird Survey (where data are usually collected by experienced technicians) or eBird data (where the data are largely contributed by citizen scientists) were found to agree (Walker and Taylor 2017).

The principal goals of this study were to better understand the habitat requirements of the imperiled Black Rail and to find new areas of suitable habitat in the eastern part of its mainland North American range (primarily on the Atlantic coastal plain). Based on previous studies of Black Rails (Legare and Eddleman 2001, Roach and Barrett 2015, Tsao et al. 2015, Tolliver et al. 2018, Haverland 2019) we predicted that the model would heavily associate characteristics indicative of high marsh with Black Rail habitat suitability such as flooded vegetation, proximity to open 
water, shallow water level, low relief topography, low slope, loose soils, wet and warm climate, and low human population density. Our approach was to quantify biotic and abiotic characteristics at sites where Black Rails have been detected and to determine what environmental factors are associated with Black Rail occupancy. Black Rail presence data were acquired from eBird. Remotely-sensed environmental data from publicly-available databases were entered into the model as predictor variables. Other sites were then identified that have similar characteristics, indicative of their possible suitability.

\section{METHODS}

\section{Spatial extent}

The spatial extent of this study was restricted to the eastern coastal plain of the United States and adjacent areas, which encompasses the region covered by the Atlantic Coast Joint Venture and includes the presumed dispersal range for the Atlantic coastal population. Our aim was to inform the Atlantic Coast Joint Venture's comprehensive conservation management plan. We included the coastal plain and contiguous areas where birds that migrate along the Atlantic flyway might reasonably disperse to. We demarcated a rectangular study area with an extent of $-87.274970 \mathrm{dd}$ to $-69.742052 \mathrm{dd}$ longitude and $44.564868 \mathrm{dd}$, 25.135401 dd latitude, the final extent used in the analysis.

\section{Data sources and acquisition}

We downloaded from eBird (eBird 2018) Black Rail detection data spanning the years 1851 to 2018. This dataset contained both points recorded by citizen scientists and historical detections added retroactively from records verified by staff of the Cornell Lab of Ornithology. Additional eBird observations were found in more westerly parts of the subspecies' range. Notably, there were multiple detections in a small region in eastern Colorado, and also across a much larger area along the gulf coast of Texas. Others were sparsely scattered across the species' range. Exploratory models we constructed based on varying the spatial extent (including different extents of the historical range of the eastern subspecies) gave us insights into how the importance of the environmental predictor variables would vary. However, the performance of these models was poor in predicting suitable habitat along the east coast. In part, this was attributable to the range-wide scarcity of eBird detections and their distributional bias along the coasts. We concluded that the best predictive models for identifying habitat suitability for this region was based on modeling the geographic extent of our specific region of interest, and we used only eBird detections that fell within this range (Table 1). The eBird points were visualized in ArcMap 10.7 and points within the study area were selected, exported and used in the analysis.

Eight environmental data layers from the Esri data bank (Table 2) were accessed from https://www.arcgis.com and added to the map in order to process them for use in the model. The "World Land Cover ESA 2010" dataset describes categories of vegetation cover types. This was chosen for the model because both previous Black Rail habitat suitability models found vegetation type and density to be important to Black Rail occupancy (Tsao et al. 2015, Haverland 2019). Other habitat association studies for the species also concluded that vegetation was important (Legare and Eddleman 2001, Roach and Barrett 2015, Tolliver et al. 2018).
Black Rails are known to be associated with wetlands, and these often surround the perimeters of lakes and form living shorelines. A layer describing "World Distance to Water" gives each cell a value indicating its distance from surface water. This layer had no data in raster cells categorized as being zero meters from open water. We therefore used ArcMap tools to assign cells with no data a value of zero to indicate open water.

A layer describing general landscape features, "World Ecological Facets Landform Classes", was used to represent the topography. This dataset uses the Hammond's landform classification which created categories based on slope, local relief, and profile. Topography of the landscape is used in some form in many ecological models (Moreno et al. 2011, Wu et al. 2012, Hu and Liu 2014, Coxen et al. 2017, Haverland 2019). The surface water category was removed due to the overlap with the land cover data water bodies category and the fact that Black Rails were not expected to be detected in areas of open water.

Underlying "Lithology" and soil type can influence vegetation and hydrology and has been shown to be influential in habitat models for birds in less vegetated areas. For species occurring in areas with limited vegetation to influence habitat selection, factors such as topography, lithology, and soil type are likely to play a larger role (Palomino et al. 2008). Black Rails have small home ranges, forage on the ground or in small pools, and build their nests on mud or moist soil (Legare and Eddleman 2001, Hand et al. 2019). Thus, we deemed it appropriate to include soil and topography in the habitat selection model.

"Terrain: Slope in Degree" was added to the model because slope influences hydrology which is known to be important to Black Rail occupancy (Richmond et al. 2008, 2010). Modifying slope to favor shallow water depths is a proposed management strategy for Black Rails (Atlantic Coast Joint Venture 2020). The "Terrain: Slope in Degrees" dataset had to be reclassified because the value number was based on the average elevation difference between adjacent cells. To correct for the change in dimension of the raster cell size, the layer was reclassified to have a continuous $0^{\circ}$ to $90^{\circ}$ scale.

The "World Population Estimate 2016" dataset was added to the model to determine if there was an association between human occupation and Black Rails, which is important when considering land management. The estimates in this dataset are based on the surface footprint of the human population. This layer had no data in raster cells categorized as having zero population, so we assigned these cells a value of zero to indicate a lack of human residency.

Previous studies have emphasized the importance to California Black Rails of permanent groundwater (Richmond et al. 2008), so the "U.S. Soils Water Table Depth" was used in the model to help inform habitat suitability. This water table depth layer did not have values for areas that were considered as having surface water and areas lacking a water table. To resolve this, areas of surface water were given a value of 0 by integrating the surface water data from the distance to water layer. All other areas lacking data were assumed to have no water table and were given a value of $256 \mathrm{~cm}$ (one $\mathrm{cm}$ more than the highest value before the modification). 
Table 1. Summary of observations downloaded from eBird within the selected spatial extent by state or province, and the subset of unique locations used as the response variable for constructing the MaxEnt model. The data are broken down into observations before and after 2002, when observers began uploading their own observations to eBird, to reflect the proportion of observations added to the database retroactively.

\begin{tabular}{|c|c|c|c|c|c|c|c|c|c|}
\hline \multirow[b]{2}{*}{$\begin{array}{l}\text { State or } \\
\text { province }\end{array}$} & \multicolumn{3}{|c|}{ eBird records } & \multicolumn{6}{|c|}{ Unique points } \\
\hline & $\begin{array}{c}\text { Total } \\
\text { observations }\end{array}$ & Before 2002 & After 2002 & $\begin{array}{l}\text { All unique } \\
\text { points }\end{array}$ & Before 2002 & After 2002 & Both & $\begin{array}{l}\text { Points with } \\
\text { multiple } \\
\text { observations }\end{array}$ & $\begin{array}{c}\text { Points with a } \\
\text { single } \\
\text { observation }\end{array}$ \\
\hline Ontario & 6 & 6 & 0 & 4 & 4 & 0 & 0 & 0 & 4 \\
\hline Connecticut & 15 & 15 & 0 & 6 & 6 & 0 & 0 & 2 & 4 \\
\hline Delaware & 44 & 22 & 22 & 6 & 0 & 4 & 2 & 3 & 3 \\
\hline $\begin{array}{l}\text { District of } \\
\text { Columbia }\end{array}$ & 3 & 3 & 0 & 1 & 1 & 0 & 0 & 1 & 0 \\
\hline Florida & 343 & 47 & 296 & 90 & 16 & 70 & 4 & 37 & 53 \\
\hline Georgia & 6 & 0 & 6 & 2 & 0 & 2 & 0 & 0 & 2 \\
\hline Indiana & 61 & 0 & 61 & 20 & 0 & 20 & 0 & 3 & 17 \\
\hline Maryland & 224 & 104 & 120 & 27 & 18 & 4 & 5 & 14 & 13 \\
\hline Massachusetts & 75 & 1 & 74 & 7 & 1 & 6 & 0 & 3 & 4 \\
\hline Michigan & 15 & 2 & 13 & 5 & 1 & 4 & 0 & 4 & 1 \\
\hline New & 10 & 0 & 10 & 6 & 0 & 6 & 0 & 2 & 4 \\
\hline \multicolumn{10}{|l|}{ Hampshire } \\
\hline New Jersey & 307 & 38 & 269 & 34 & 10 & 20 & 4 & 16 & 18 \\
\hline New York & 26 & 19 & 7 & 12 & 6 & 6 & 0 & 2 & 10 \\
\hline North & 169 & 61 & 108 & 35 & 13 & 15 & 7 & 16 & 19 \\
\hline \multicolumn{10}{|l|}{ Carolina } \\
\hline Ohio & 62 & 3 & 59 & 20 & 2 & 18 & 0 & 7 & 13 \\
\hline Pennsylvania & 24 & 10 & 14 & 16 & 10 & 6 & 0 & 3 & 13 \\
\hline Rhode Island & 13 & 0 & 13 & 4 & 0 & 4 & 0 & 1 & 3 \\
\hline South & 96 & 20 & 76 & 16 & 3 & 10 & 3 & 7 & 9 \\
\hline \multicolumn{10}{|l|}{ Carolina } \\
\hline Tennessee & 1 & 1 & 0 & 1 & 1 & 0 & 0 & 0 & 1 \\
\hline Virginia & 62 & 15 & 47 & 12 & 2 & 9 & 1 & 4 & 8 \\
\hline West Virginia & 37 & 1 & 36 & 30 & 1 & 29 & 0 & 3 & 27 \\
\hline Total & 1599 & 368 & 1231 & 354 & 95 & 233 & 26 & 128 & 226 \\
\hline
\end{tabular}

Finally, "World Bioclimate" data were added to the model. Most ecological niche models use some form of climate data when modeling species distributions over a large area (Phillips et al. 2004, 2006, Moreno et al. 2011, Wu et al. 2012, Hu and Liu 2014, Coxen et al. 2017). This dataset uses temperature and aridity descriptions which are appropriate to characterize climatic conditions across this range.

\section{File manipulation and resampling}

The raster analysis cell size for all datasets was set to the resolution of the geographically coarsest dataset $\left(928 \mathrm{~m} \mathrm{X} 928 \mathrm{~m}, 0.86 \mathrm{~km}^{2}\right)$ or approximately a square kilometer. When the layers were copied, the raster grids were resampled to this cell size using the nearest neighbor method, which defines the value of the larger cell by assigning the value of the smaller cell closest to the center of the larger cell when being resampled. All of the modified raster layer files were converted to ASCII files.

Under a systematic data collection protocol with the objective of determining species presence by surveying an area multiple times, multiple observations in the same vicinity would help strengthen a spatial model by adding meaningful information about species density. With eBird data, there is no formal collection protocol. Yet, there were incidences of multiple observations for the exact same coordinates, possibly submitted for the same bird by multiple observers. These stochastic multiple entries for the same coordinates are meaningless for the model. For this reason, repeat detections with the exact same coordinates were eliminated.
The eBird dataset had 1599 observations of Black Rail within the bounds of the area set for this study. Of these observations, 368 of them had observation dates before 2002 when the eBird database was created (Table 1). After eliminating replicate detections, we were left with 354 unique points used to construct the model. Removing replicates mitigates bias in the eBird data while retaining a reasonable sample size. Of the 354 unique points used to build the model, 95 of them had detections exclusively before 2002, 233 points had observations exclusively in or after 2002, and 26 points had observations both before and after 2002 (Table 1).

\section{Model selection}

To select the best habitat suitability model, we used the MaxEntVariableSelection package in R (Jueterbock et al. 2016, $\mathrm{R}$ Core Team 2019). We used our Black Rail occurrence file and produced a background file (Sample With Data file, SWD) of random points representing no occurrence, each containing the geographic coordinates along with columns for each environmental variable. In the absence of having points known to be lacking Black Rails, a random selection of pseudo-absence points were created (Jueterbock et al. 2016). Using a Python script in ArcMap, 10,000 background points within the study extent were randomly selected from raster cells classified as being nonsurface water that did not contain Black Rail eBird detections. Of the randomly selected points, 33 had missing values for one or more of the environmental layers, reducing the background file to 9967 points. 
Table 2. Environmental predictor variables used to develop the full habitat suitability model for Black Rails on the Atlantic coastal plain using occurrence records derived from eBird. The scale indicated is the original definition of the variable in Esri before the variables were rescaled to a common raster size of $928 \mathrm{~m} \mathrm{X} 928 \mathrm{~m}\left(0.86 \mathrm{~km}^{2}\right)$.

\begin{tabular}{|c|c|c|c|}
\hline Environmental predictor & Description & Original sampling resolution & Data source \\
\hline World Land Cover ESA 2010 & $\begin{array}{l}\text { The surface of the earth classified into } \\
36 \text { classes focused on vegetation type, } \\
\text { including agriculture, forests, grasslands, } \\
\text { artificial surfaces, and other categories. }\end{array}$ & $300 \mathrm{~m}$ & $\begin{array}{l}\text { Esri, ESA } \\
\text { (https://www.arcgis.com/home/) }\end{array}$ \\
\hline World Distance to Water & $\begin{array}{l}\text { Distance in meters from surface water } \\
\text { calculated using Euclidian distance }\end{array}$ & $250 \mathrm{~m}$ & Esri, USGS, ESA \\
\hline World Ecological Facets Landform & Topographic classification based on & $232 \mathrm{~m}$ & Esri \\
\hline Classes & $\begin{array}{l}\text { Hammond Landform Classification } \\
\text { combining slope, relief, and profile }\end{array}$ & & \\
\hline World Lithology & $\begin{array}{l}\text { Classification of underlying soils and } \\
\text { rock }\end{array}$ & $250 \mathrm{~m}$ & Global Lithological Map Database v1.0 \\
\hline U.S. Soils Water Table Depth & $\begin{array}{l}\text { Shallowest depth to water in the soil at } \\
\text { any time of the year in centimeters in } \\
\text { the United States and territories }\end{array}$ & $30 \mathrm{~m}$ & USDA NRCS, Esri \\
\hline World Population Estimate 2016 & $\begin{array}{l}\text { Global estimate of human population } \\
\text { for } 2016 \text { based on human settled area } \\
\text { footprint }\end{array}$ & $\sim 150 \mathrm{~m}$ & Esri \\
\hline Terrain: Slope in Degrees & $\begin{array}{l}\text { Slope values calculated dynamically } \\
\text { from the elevation data (within the } \\
\text { current extents) using the server-side } \\
\text { slope function applied to a Terrain layer }\end{array}$ & $0.25 \mathrm{~m}$ & $\begin{array}{l}\text { Airbus, USGS, NGA, NASA, CGIAR, } \\
\text { NLS, OS, NMA, Geodatastyrelsen, } \\
\text { GSA, GSI and the GIS User } \\
\text { Community }\end{array}$ \\
\hline World Bioclimate & $\begin{array}{l}\text { Climate classification combining } \\
\text { temperature and aridity categories }\end{array}$ & $928 \mathrm{~m}$ & $\begin{array}{l}\text { Esri, USGS, } \\
\text { Metzger et al. } 2012\end{array}$ \\
\hline
\end{tabular}

We conducted model selection using MaxEntVariableSelection starting with the full model of eight environmental variables and running subsets of environmental variables while varying Beta multipliers ranging from 1-5 with 0.5-point increments (Table 3 ). We tested ten different multipliers. Using only the hinge feature, we ran ten replicates of each model. The random test percentage was set to 50 percent. We compared the models according to criteria of corrected Akaike's Information Criterion (AICc) and "Area Under the Receiver Operating Characteristic Curve" (AUC). The AUC is a threshold independent measure with a value range of 0 to 1 . An AUC value of 1 indicates a model with perfect predictive ability and a value of 0.5 indicates a model with predictive abilities no better than random (Phillips et al. 2004, 2006). To determine which combination of variables produced the most predictive model, we set the contribution threshold to $5 \%$ (to exclude any variables with lower contributions) and a correlation threshold of $90 \%$ to exclude highly correlated variables (Jueterbock et al. 2016).

\section{Model evaluation}

The full model and the selected top model were each replicated using the MaxEnt desktop program (v. 3.4.1) in order to obtain habitat suitability maps and response curves for the environmental variables. The Black Rail presence file was used as the sample file and the background SWD file as the input for the environmental layers and a folder that contained the ASCII files of the modified environmental layers as the projection layers directory. Adding the projected layers directory allowed the program to create a map. The random test percentage was set to 50 percent, number of replicates was set to ten, replicate run type set to "subsample", and the hinge feature was the only feature used. Response curves and jackknife plots were generated from these models. To replicate the model with the lowest AICc, only
Population and Water table were excluded from the model. Response curves were used to determine what values or categories of each environmental variable were strongly associated with Black Rail presence based on their relative degrees of association. We used percent contribution of each variable to the model as the main criterion for assessing its importance. Secondarily, we also considered the variable's influence on the gain of the model and its permutation importance.

\section{RESULTS}

Inspection of the North American eBird dataset revealed that within the range of the eastern subspecies, the density of detections on the east coast was greater than in other regions. The only other areas with significant numbers of detections were the Gulf Coast of Texas and a small region in eastern Colorado that had a scattering of observations. Outside of these areas, eBird detections were sparse and separated by large tracts devoid of suitable habitat (e.g., human-modified areas, areas of high relief, etc.). Our aim, however, was to model the Black Rail population on the eastern coastal plain, and the density of eBird observations was higher in the southeastern region.

Upon examination of the model selection results, Water table depth, human Population, and Bioclimate were the variables that consistently had the least influence on the model. The top model with the lowest AICc (Model 2, top of Table 3) retained the variable Bioclimate, though it barely met the contribution level threshold of $5 \%$. When we ran the same model (Model 2) on the desktop version of MaxEnt, it had a mean test AUC of 0.855 , and Bioclimate cleared the threshold with mean contribution of $5.5 \%$ over ten replicates (Table 4 ). This was considered the final model and was used to characterize the contributions of individual environmental variables (Table 4). 
Table 3. Summary of performance indicators of a subset of the MaxEnt models tested using the MaxEntVariableSelection package in R. Full models used all 8 variables and the others used different subsets of variables in combination with Beta multipliers ranging from 1 to 5 in 0.5 increments. This table lists the models that returned the lowest corrected Akaike's Information Criterion (AICc) values, and performance indicators are the means of ten replicates. The results are sorted by AICc, with the best performing model at the top (Model 2 with a Beta multiplier of 1). The full model with a Beta multiplier of 1 had the second lowest AICc. The Area Under the Receiver Operating Characteristic Curve (AUC) values are presented for the test data, the training data and the difference between the two. Model 5 had the highest test AUC and the smallest difference between test and training datasets.

\begin{tabular}{|c|c|c|c|c|c|c|c|c|c|}
\hline Model ID & Beta multiplier & No. variables & $\begin{array}{c}\text { No. } \\
\text { parameters }\end{array}$ & $\begin{array}{c}\log \\
\text { likelihood }\end{array}$ & $\overline{\mathrm{AICc}}$ & $\Delta \mathrm{AICc}$ & $\begin{array}{c}\text { AUC } \\
\text { Test }\end{array}$ & $\begin{array}{c}\text { AUC } \\
\text { Training }\end{array}$ & $\begin{array}{c}\text { AUC } \\
\text { Difference }\end{array}$ \\
\hline 2 & 1 & 6 & 44 & -4728.22 & 9557 & 0 & 0.8535 & 0.8791 & 0.0256 \\
\hline 1 & 1 & 8 & 50 & -4723.21 & 9563 & 6 & 0.8510 & 0.8831 & 0.0321 \\
\hline 6 & 1.5 & 8 & 44 & -4733.10 & 9567 & 10 & 0.8512 & 0.8764 & 0.0252 \\
\hline 12 & 2 & 6 & 42 & -4741.07 & 9578 & 21 & 0.8569 & 0.8659 & 0.0090 \\
\hline 21 & 3 & 6 & 34 & -4753.99 & 9583 & 26 & 0.8525 & 0.8644 & 0.0119 \\
\hline 11 & 2 & 8 & 45 & -4742.49 & 9588 & 31 & 0.8538 & 0.8682 & 0.0144 \\
\hline 16 & 2.5 & 8 & 40 & -4753.02 & 9597 & 39 & 0.8542 & 0.8684 & 0.0142 \\
\hline 3 & 1 & 5 & 42 & -4752.58 & 9601 & 44 & 0.8556 & 0.8742 & 0.0186 \\
\hline 4 & 1 & 5 & 42 & -4752.58 & 9601 & 44 & 0.8549 & 0.8737 & 0.0188 \\
\hline 5 & 1 & 5 & 42 & -4752.58 & 9601 & 44 & 0.8603 & 0.8692 & 0.0089 \\
\hline 13 & 2 & 5 & 35 & -4762.58 & 9603 & 46 & 0.8383 & 0.8757 & 0.0374 \\
\hline 14 & 2 & 5 & 35 & -4762.58 & 9603 & 46 & 0.8545 & 0.8670 & 0.0125 \\
\hline 15 & 2 & 5 & 35 & -4762.58 & 9603 & 46 & 0.8504 & 0.8706 & 0.0202 \\
\hline 7 & 1.5 & 5 & 41 & -4757.62 & 9608 & 51 & 0.8486 & 0.8749 & 0.0263 \\
\hline 8 & 1.5 & 5 & 41 & -4757.62 & 9608 & 51 & 0.8578 & 0.8679 & 0.0101 \\
\hline 9 & 1.5 & 5 & 41 & -4757.62 & 9608 & 51 & 0.8511 & 0.8725 & 0.0214 \\
\hline 10 & 1.5 & 5 & 41 & -4757.62 & 9608 & 51 & 0.8525 & 0.8690 & 0.0165 \\
\hline 17 & 2.5 & 5 & 35 & -4767.02 & 9612 & 55 & 0.8454 & 0.8683 & 0.0229 \\
\hline 22 & 3 & 5 & 40 & -4770.50 & 9631 & 74 & 0.8448 & 0.8659 & 0.0211 \\
\hline 20 & 3 & 8 & 48 & -4760.45 & 9632 & 75 & 0.8493 & 0.8678 & 0.0185 \\
\hline 24 & 3.5 & 8 & 45 & -4768.31 & 9640 & 83 & 0.8391 & 0.8695 & 0.0304 \\
\hline 32 & 4.5 & 8 & 36 & -4783.17 & 9647 & 89 & 0.8415 & 0.8613 & 0.0198 \\
\hline 28 & 4 & 8 & 43 & -4776.02 & 9650 & 93 & 0.8490 & 0.8633 & 0.0143 \\
\hline 36 & 5 & 8 & 34 & -4789.56 & 9655 & 97 & 0.8373 & 0.8635 & 0.0262 \\
\hline 18 & 2.5 & 4 & 27 & -4798.49 & 9656 & 98 & 0.8265 & 0.8500 & 0.0235 \\
\hline 19 & 2.5 & 4 & 27 & -4798.49 & 9656 & 98 & 0.8312 & 0.8476 & 0.0164 \\
\hline 23 & 3 & 4 & 30 & -4801.65 & 9669 & 112 & 0.8172 & 0.8493 & 0.0321 \\
\hline 25 & 3.5 & 4 & 29 & -4805.19 & 9674 & 116 & 0.8277 & 0.8379 & 0.0102 \\
\hline 26 & 3.5 & 4 & 29 & -4805.19 & 9674 & 116 & 0.8256 & 0.8397 & 0.0141 \\
\hline 27 & 3.5 & 4 & 29 & -4805.19 & 9674 & 116 & 0.8258 & 0.8419 & 0.0161 \\
\hline 33 & 4.5 & 5 & 37 & -4800.03 & 9683 & 126 & 0.8202 & 0.8478 & 0.0276 \\
\hline 29 & 4 & 4 & 30 & -4809.12 & 9684 & 127 & 0.8193 & 0.8413 & 0.0220 \\
\hline 30 & 4 & 4 & 30 & -4809.12 & 9684 & 127 & 0.8250 & 0.8351 & 0.0101 \\
\hline 31 & 4 & 4 & 30 & -4809.12 & 9684 & 127 & 0.8213 & 0.8385 & 0.0172 \\
\hline 37 & 5 & 4 & 31 & -4817.87 & 9704 & 147 & 0.8093 & 0.8338 & 0.0245 \\
\hline 38 & 5 & 4 & 31 & -4817.87 & 9704 & 147 & 0.8133 & 0.8360 & 0.0227 \\
\hline 39 & 5 & 4 & 31 & -4817.87 & 9704 & 147 & 0.8081 & 0.8322 & 0.0241 \\
\hline 34 & 4.5 & 4 & 35 & -4813.39 & 9705 & 147 & 0.8159 & 0.8389 & 0.0230 \\
\hline 35 & 4.5 & 4 & 35 & -4813.39 & 9705 & 147 & 0.8144 & 0.8378 & 0.0234 \\
\hline
\end{tabular}

Land cover class was most predictive of Black Rail presence, yielding the greatest influence independently, hence accounting for the greatest amount of information not explained by the other variables (Fig. 1). Land cover class, which described the vegetation structure, had the highest percent contribution and permutation importance (Table 4). Land cover classes that had the highest responses were "flooded shrub or herbaceous cover", "closed to open canopy, needleleaved deciduous tree cover", "bodies of water", "saline water flooded tree cover", and "bare areas" (Fig. 2a).

Distance to water had the next highest percent contribution (Table 4) and the next highest gain in the jackknife plot indicating its importance to the model (Fig. 1). The response plot for distance to water shows a precipitous drop in probability of finding Black Rails the farther away one travels from water (Fig. 3a).
Fig. 1. Jackknife of test gain for the final model (Model 2, Beta multiplier =1). The change in model gain, or effectiveness, is illustrated when the indicated variable is excluded (green) or used exclusively (blue). The gain when all variables are included is shown in red.

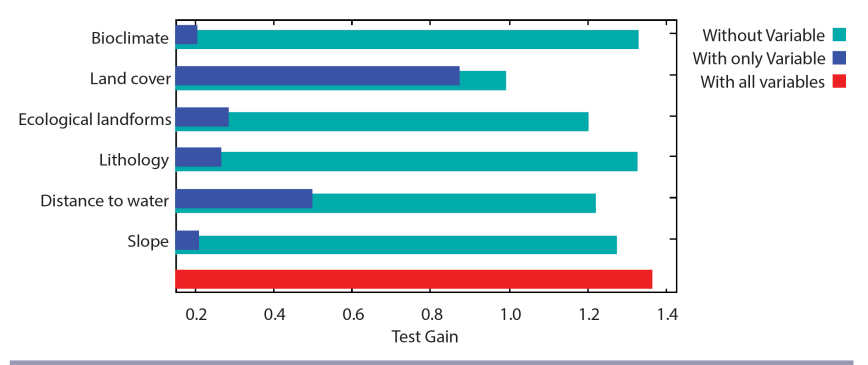


Fig. 2. Environmental variable response plots for each categorical variable entered into the final model $($ Model 2, Beta multiplier $=1)$. Probability of Black Rail presence is expressed as the complimentary log-log transformation as the independent response in relation to (a) Land cover classes, (b) Ecological landform classes, (c) Lithology classes and (d) Bioclimate classes. Mean ( \pm SE) responses are shown based on ten replicate Maxent runs.

(a)

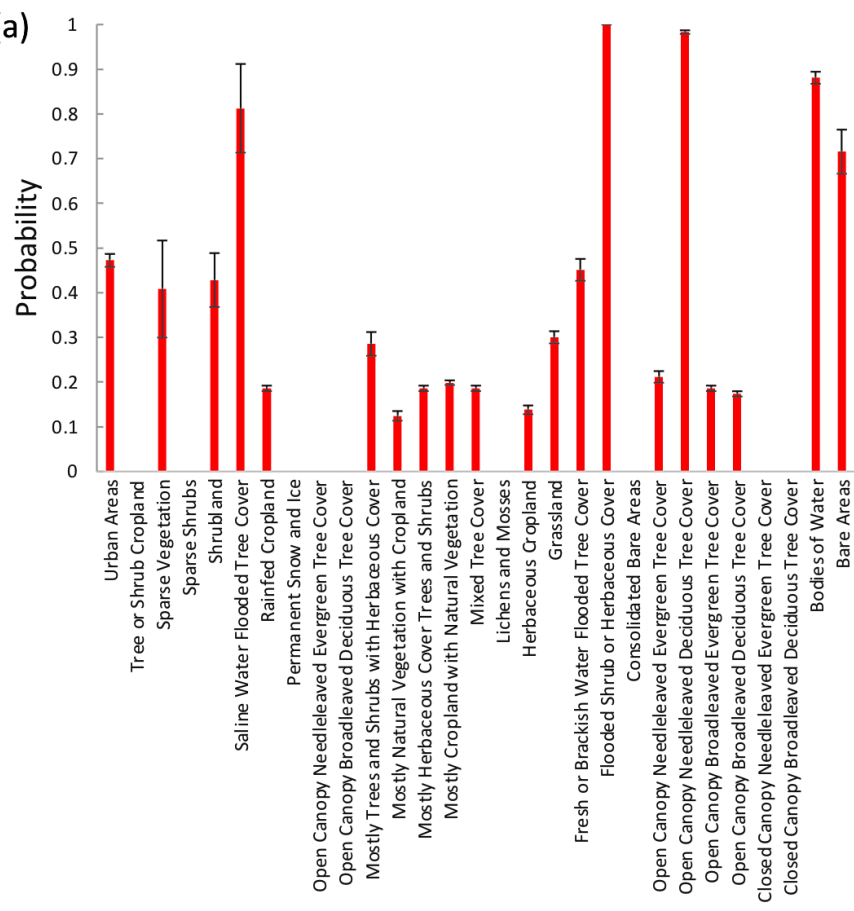

(b)

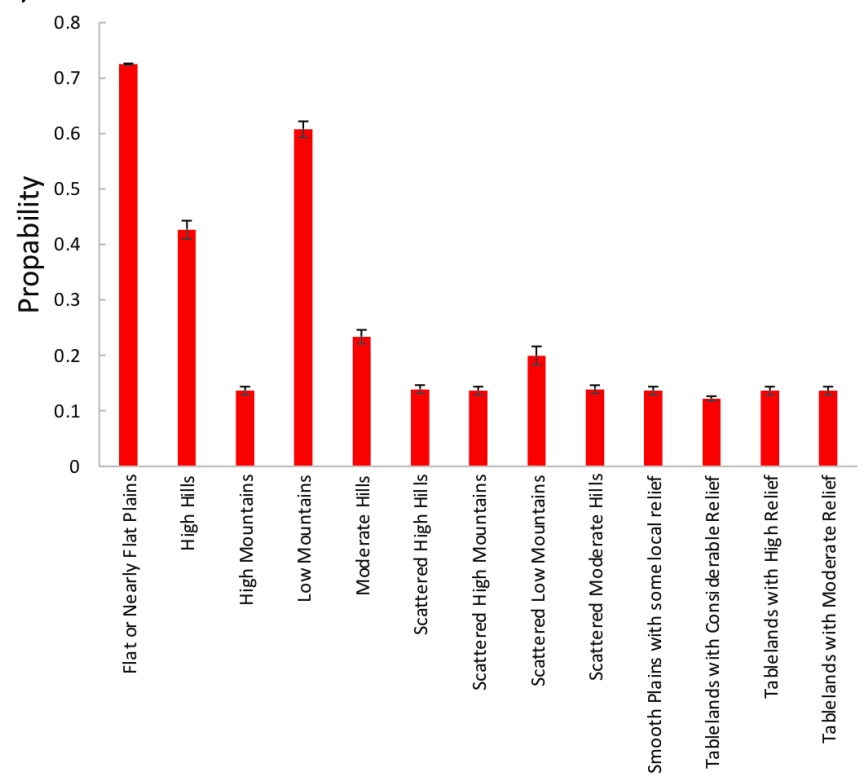

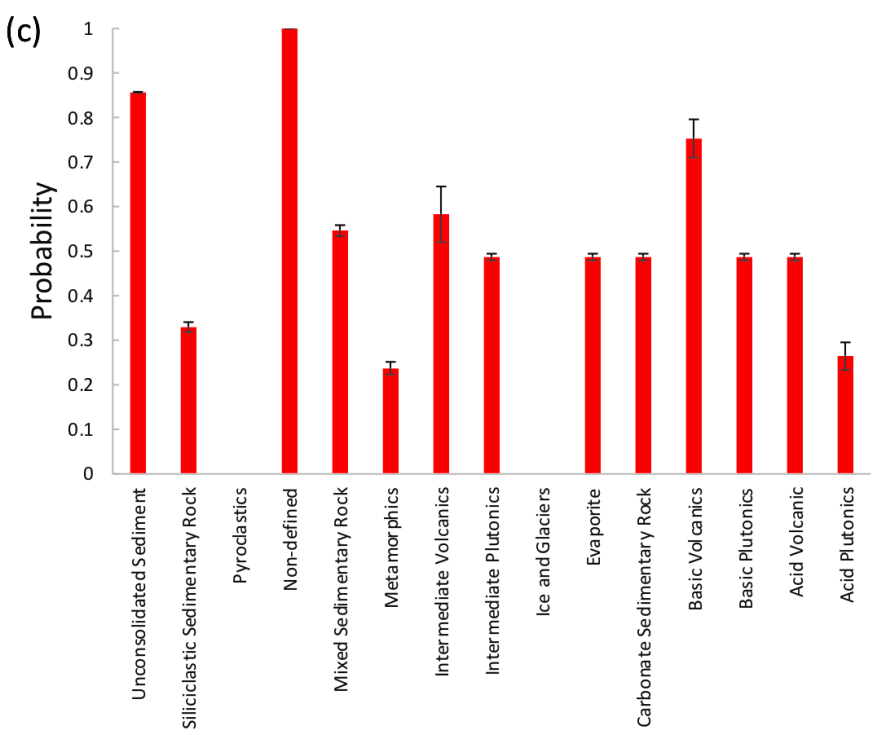

Lithology classes

(d)

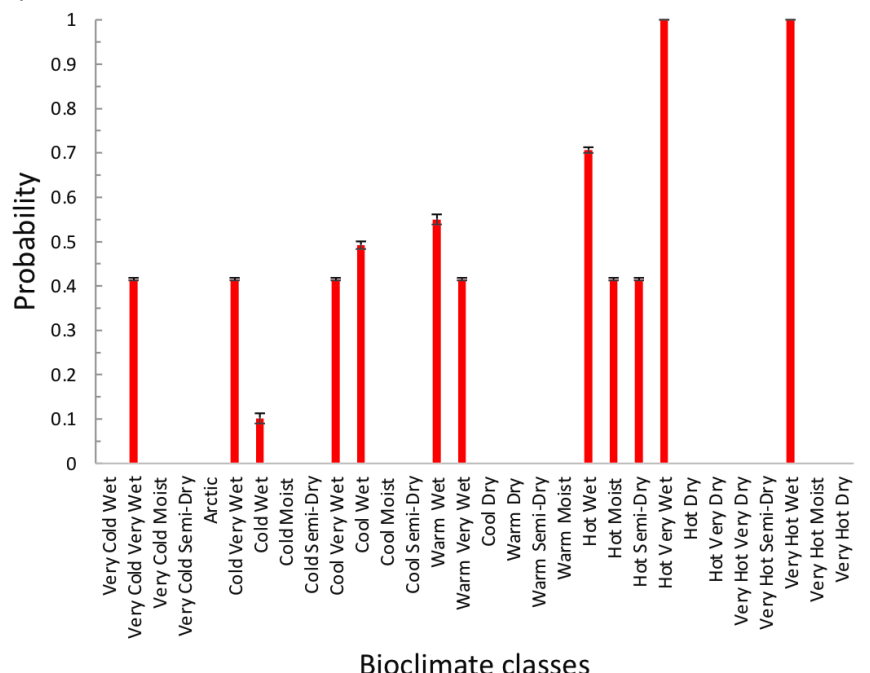

Bioclimate classes

The next most important variables were the Ecological landform classes and Lithology (Fig. 1, Table 4). The category of Ecological landforms that stood out was "flat or nearly flat plains", but the relatively high association with "low mountains" is noteworthy (Fig. 2b). The Lithology data described soil types and was almost equivalent in contribution though lower in permutation importance with fairly low percent contribution (Table 4). The soil types associated with the strongest responses were "unconsolidated sediment", "non-defined", and "basic volcanic" (Fig. 2c).

The Slope variable had a lower percent contribution but the second highest permutation importance score (Table 4). Permutation 
Table 4. Performance criteria for the top model (Model 2, Beta multiplier =1). Model output is from the MaxEnt desktop run (see also Figs. 1-4). The percent contribution of each variable is based on the increase in regularized gain contributed by the variable. The permutation importance of each variable is based on the effect on the model of randomly permuting only that variable, and the resulting drop in the training AUC normalized to percentages.

\begin{tabular}{lcc}
\hline \hline Variable & Percent contribution & $\begin{array}{c}\text { Permutation } \\
\text { importance (\%) }\end{array}$ \\
\hline Land cover & 47.6 & 27.0 \\
Distance to water & 24.2 & 16.6 \\
Lithology & 8.6 & 4.1 \\
Ecological landforms & 8.0 & 18.8 \\
Slope & 6.2 & 22.5 \\
Bioclimate & 5.5 & 11.1 \\
\hline
\end{tabular}

Fig. 3. Environmental variable response curves for each continuous variable entered into the final model (Model 2, Beta multiplier = 1) Probability of Black Rail presence is expressed as the complimentary log-log transformation in relation to (a) Distance from water (m) and (b) Slope (degrees). These plots reflect the dependence of Black Rail habitat suitability on the selected variable and on dependency induced by correlation to other variables. Curves show the mean responses of ten replicate MaxEnt runs $\pm \mathrm{SD}$ (blue).
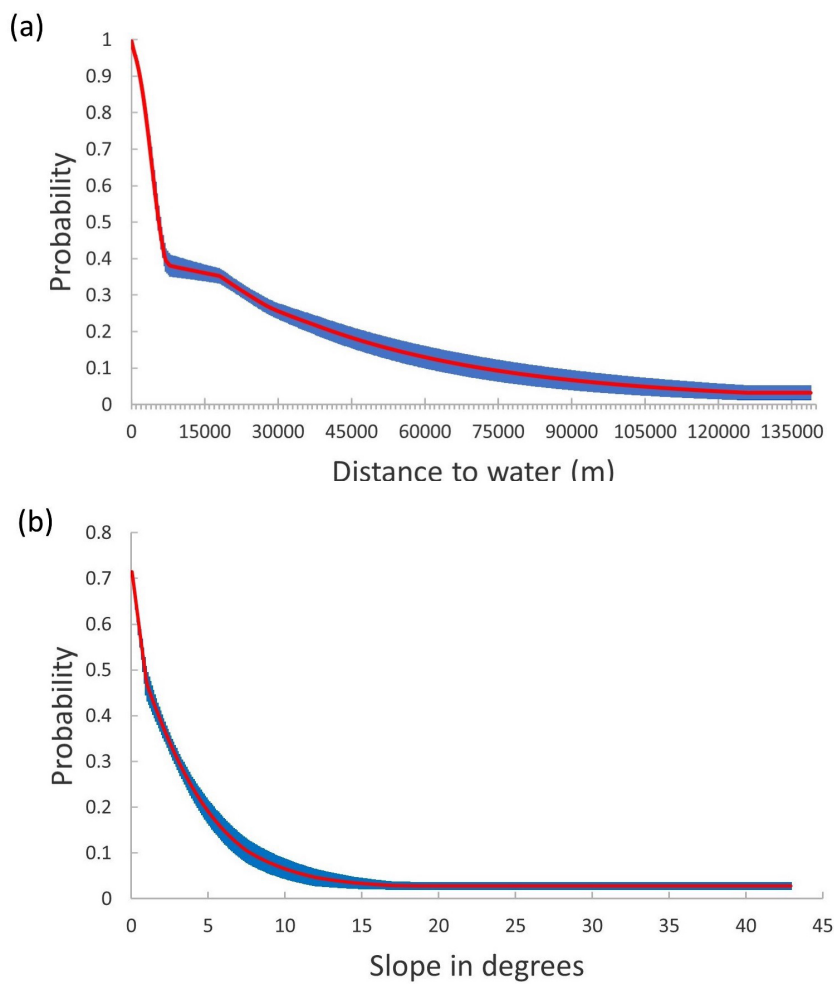

importance is another measure of the influence of the variable on the model. The response curve showed a steep drop between slopes of $0^{\circ} \sim 4^{\circ}$ and then a steadier decline in probability as slope increased (Fig. 3b). The low percent contribution of the Slope variable likely reflects the fact that a lot of area along the coastal plain is flat or has only a very gentle slope, but not all of these areas are suitable for Black Rails. Yet, the relatively high permutation importance indicates that areas with very significant slope are generally not going to be well suited to Black Rails.

Bioclimate was the least explanatory variable to make the cut in the top model. The categories that were most predictive of Black Rails all contained the descriptors "hot" and "wet" (Fig. 2d), reflecting that more suitable habitat was found at lower latitudes. Nevertheless, the percent permutation importance of the variable was relatively low (Table 4).

The map created by the final model shows that suitable habitat is generally on the coast with only sparse small pockets inland (Fig. 4). Several hotspots emerged that have larger tracts of suitable habitat. Some of these are areas known for recent occupancy such as the Maryland shore of the Chesapeake Bay (Wilson et al. 2007), the Pamlico peninsula of North Carolina (Wilson et al. 2016), and the ACE Basin region of South Carolina (Hand et al. 2019). However, the map also revealed land not currently regarded as hosting Black Rails including significant tracts of the South Carolina and Georgia coastlines, areas on the southern coast of Florida and surrounding the Everglades, and coastal New Jersey. Smaller inland areas that are promising for Black Rails were also identified; these can be better seen on higher-resolution maps (available from the authors).

\section{DISCUSSION}

We selected the geographic extent of the Atlantic coastal states, the region of interest for the recently completed conservation action plan of the Atlantic Coast Joint Venture. This extent gave a robust model that identified habitat characteristics predictive of Black Rail occupancy. The environmental factor that was most explanatory was land cover, and the specific categories identified were pertinent descriptors of specific wetland types found in the east: generally flooded areas with herbaceous and other wetland vegetation types.

The final model for Black Rail habitat suitability included land cover, distance to water, ecological landforms, lithology, slope, and bioclimate. This model was selected for having the lowest AICc. There was scant difference in AUC values among top models. Our top model AUC (0.855) was well within the acceptable range and consistent with other MaxEnt models for birds (Moreno et al. 2011 [AUC $=0.87$ and 0.99], Wu et al. 2012 [AUC $=0.7-0.98], \mathrm{Hu}$ and Liu 2014 [AUC $=0.81$ ], Tsao et al. 2015 [AUC=0.92], Haverland 2019 [AUC=0.67]).

The factor most associated with Black Rail presence in this model was land cover, and specifically flooded shrub and herbaceous vegetation. All of the land cover categories that had the highest responses in the model support the hypothesis that flooding in association with vegetation (characteristics of wetlands) were important. These were all categories that fit the high marsh habitat that Black Rail were found to occupy in another habitat association study that looked at vegetation type on the Gulf coast in Texas (Haverland 2019). 
Fig. 4. Eastern Black Rail habitat suitability across the Atlantic coastal plain of the U.S. created using the final optimized MaxEnt model (Model 2, Beta multiplier =1). The color scale indicates the probability of Black Rail habitat with warm colors and higher values predicting greater suitability. Terrestrial areas coded white lacked data for one or more environmental variables.

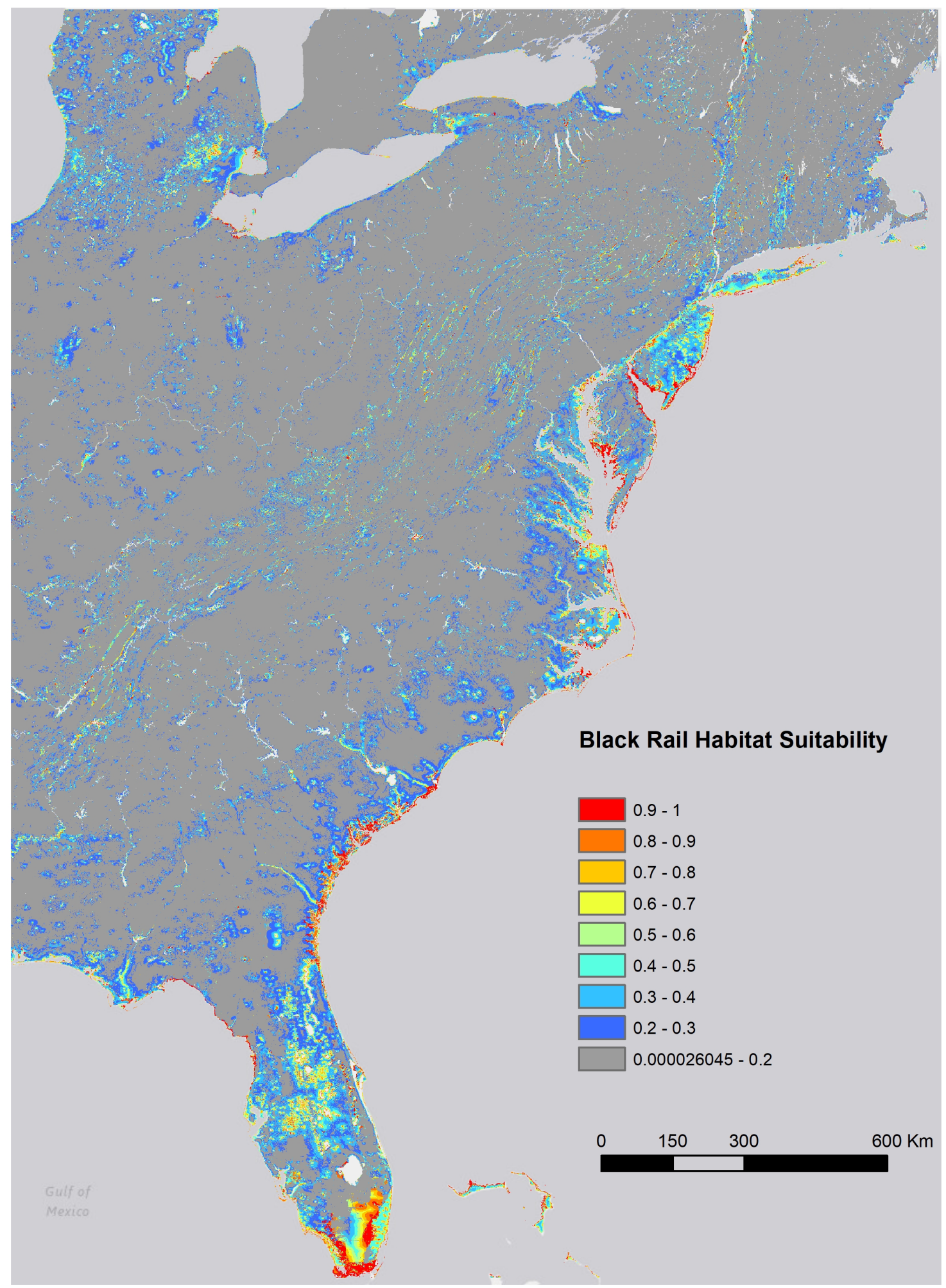


As predicted for a wetland bird, proximity to water was also important. It is reasonable to assume that most marsh habitat would be classified as being within a kilometer of water. In California, using habitat data collected at each survey site, Black Rail presence was shown to be correlated with proximity to channels (Tsao et al. 2015). Our model agrees with the finding that Black Rails are associated with proximity to open water, notwithstanding its larger scale and use of citizen science data.

Among the ecological landform classes, flat land was most predictive, also supporting our hypothesis considering that, in a remote-sensing framework, marshes typically have little to no above-water topographic relief. Even in areas with more surrounding topography than the Atlantic coastal plain, it has been shown previously that Black Rails choose relatively level areas. We found a secondary association with low mountains, which is also consistent with a study of California Black Rails in the Sierra Nevada foothills. Though the scale used in our model would not likely be able to discriminate this, in this hilly region, California Black Rails were found mostly at locations with relatively little slope or elevation (Richmond et al. 2010).

The high response for unconsolidated lithology is logical because flooded soils associated with marshes generally have loose sediment (Gornitz et al. 1994). Unconsolidated soils make up a large portion of the Atlantic coastal plain and are most vulnerable to erosion, adding to the sensitivity of salt marsh habitat (Gornitz et al. 1994). Another significant lithology type identified by the model, volcanic soils of basic $\mathrm{pH}$, had lower predictability than the unconsolidated category. There were comparatively few raster cells entered into this model with volcanic lithology (basic: 10,250 cells or $0.3 \%$; intermediate: 2,639 cells or $0.08 \%$ ) on the East Coast. However, in the few places Black Rails have been recorded, these lithology types were overrepresented. This was one of the more variable findings among model replicates, suggesting it may be an artifact of small sample size. Considering the possibility that there may be something favorable about these lithology types to Black Rails, volcanic soils are known to be comparatively mineral- and nutrient-rich, promoting plant growth (Shamshuddin et al. 2011) and thus likely enhanced levels of arthropod and other prey. This possibility warrants further investigation. Nevertheless, considering the low permutation importance of the lithology data, they had comparatively little influence on the model as a whole.

California Black Rails live in a severely water-limited environment in the Sierra Nevada foothills, and their occupancy is strongly related to the presence of even small tracts of marsh (depressional, fluvial, fringe marsh, or slope) (Richmond et al. 2010). That flooding is an important habitat requirement is evidenced by rapid colonization occurring within a year of marsh creation (Richmond et al. 2008). On the East Coast, water is not limiting to the same extent, but presence of permanent water remains important. Previous studies provide evidence that a moderate slope facilitates the essential hydrology required for Black Rail habitat (Nadeau and Conway 2015, Atlantic Coast Joint Venture 2020). Persistent shallow water is difficult to achieve in flat areas that are flooded, but the presence of a gentle slope in a permanent wetland means that while the water may rise and recede, there should always be an area within the favorable range of depth. The percent contribution of slope in the final model emphasized less importance of sloped landscape. However, considering that marsh habitat has on average little topographic relief, it is unsurprising that having less slope overall is what a model of this scale predicts. Quantifying habitat characteristics, including slope, on a more regional scale in California, Black Rails were found in areas with an average slope of only 3.7 degrees (Richmond et al. 2008). Representing the moderate degree of slope required locally for suitable hydrology in natural habitats is probably not compatible with the scale of this model.

The categories of bioclimate predicting Black Rails were those describing high temperature and high humidity and precipitation. Though climate had limited importance to our model, it is clear that these tiny rails are primarily resident at lower latitudes with hotter, wetter climate data. The species is also found in the neotropics (Taylor and van Perlo 1998, BirdLife International 2021). Where they have been reported in northeastern states, they are migratory (Watts 2016).

In developing our model, we excluded replicate eBird detections from identical coordinates that we reasoned were likely submitted by observers reporting the same bird. However, we retained detections reported at different coordinates that then fell within the same raster cell $\left(\sim 1 \mathrm{~km}^{2}\right)$. Given that the home range of Black Rails is closer to $0.01 \mathrm{~km}^{2}$ (Legare and Eddleman 2001) and that they are territorial in the breeding season, it is more likely that detections at different coordinates were of different birds. Black rail detections are very rare. Though the model does not explicitly incorporate density, inclusion of multiple detections at important sites of occupancy increased the power of the model in emphasizing key variable classes.

Human population density is a concern when dealing with sensitive species, especially when considering land management (i.e., where to invest in land preservation and restoration projects) (Jarnevitch et al. 2016). Our full model supported the prediction that probability of Black Rail presence is negatively related to human population density, although the percent contribution did not meet the threshold for inclusion in the final model. Rails have been declining in coastal areas in the southeast where human development has increased substantially over the same period (Crossett et. al. 2004, Crossett et. al. 2013). Future studies should investigate whether there is a causal effect of human disturbance on Black Rail occupancy.

Our model illustrates that suitable habitat remains for Eastern Black Rails both on the coast and farther inland. These rare inland sites may become especially important as refuges for Black Rails as coastal marshes disappear due to sea level rise or human development (Nicholls 2004). Due to predicted loss of coastal wetlands, an explicit goal of the Eastern Black Rail conservation plan is to increase non-tidal habitat for Black Rails (Atlantic Coast Joint Venture 2020). The habitat suitability map generated by this model identifies areas that should be explored for Black Rail occupancy and considered for future management and/or restoration.

This model is the first to predict habitat suitability for Black Rails on the east coast of the United States. It adds to a growing list of studies showing that models using distribution data collected through citizen science can have significant predictive ability. Data from eBird can be used to generate models independently, as we 
demonstrate here, or they can supplement survey data such as breeding bird survey data to forecast future habitat suitability (Nixon et al. 2016). Areas that our model predicted would have high habitat suitability were consistent with historically known locations (Watts 2016, U.S. Fish and Wildlife Service 2018a, Atlantic Coast Joint Venture 2020). Furthermore, the model corroborated the same general habitat requirements for Black Rail found in California, Texas, and other parts of the species' range (Tsao et al. 2015, Haverland 2019), namely flooding in association with herbaceous and shrubby vegetation, also apply to the broader East Coast range. This model better elucidated the environmental variables that are most predictive of Black Rail occupancy. The most influential variables were characteristic of high marsh, confirming the importance of this habitat type to Black Rails. The map product will be useful for finding areas that are likely to support Black Rails now and in the future, and help inform land management decisions in support of species conservation.

Responses to this article can be read online at: https://www.ace-eco.org/issues/responses.php/1919

\begin{abstract}
Acknowledgments:
We sincerely thank Adam Smith and Mike Hoff for their support and advice, Michael Brewer for introducing us to maximum entropy models, ECU's Department of Biology for facilities, and members of the McRae Lab for helpful discussion. The study was supported by a grant from the U.S. Fish and Wildlife Service refuge system's Inventory and Monitoring Program administered through the Piedmont-South Atlantic Coast Cooperative Ecosystems Studies Unit to SBM and a North Carolina Wildlife Federation Scholarship to AAN. Chris Balakrishnan, Ariane Peralta, and Erin Field as well as two anonymous reviewers provided helpful comments on earlier versions of the manuscript.
\end{abstract}

\section{LITERATURE CITED}

Atlantic Coast Joint Venture. 2020. Eastern Black Rail Conservation Plan for the Atlantic Coast. [online] URL: https:// www.acjv.org

BirdLife International. 2020. IUCN red list of threatened species: Black Rail. IUCN Red List of Threatened Species. https://www. iucnredlist.org/en

BirdLife International. 2021. Species factsheet: Laterallus jamaicensis. [online] URL: http://www.birdlife.org on 23/01/2021.

Bradter, U., L. Mair, M. Jönsson, J. Knape, A. Singer, and T. Snäll. 2018. Can opportunistically collected citizen science data fill a data gap for habitat suitability models of less common species? Methods in Ecology and Evolution 9(7):1667-1678. https://doi. org/10.1111/2041-210X.13012

Corsi, F., J. de Leeuw, and A. Skidmore. 2000. Modeling species distribution with GIS. In L Boitani and T. Fuller, editors. Research Techniques in Animal Ecology. Columbia University Press, New York, pp. 389-434.
Coxen, C. L., J. K. Frey, S. A. Carleton, and D. P. Collins. 2017. Species distribution models for a migratory bird based on citizen science and satellite tracking data. Global Ecology and Conservation 11:298-311. https://doi.org/10.1016/j.gecco.2017.08.001

Crossett, K.M., T.J. Culliton, P.C. Wiley, and T.R. Goodspeed. 2004. Population trends along the coastal United States: 1980-2008. Coastal Trends Report Series (vol. 55). US Department of Commerce, National Oceanic and Atmospheric Administration, National Ocean Service, Management and Budget Office, Special Projects. Silver Spring, MD.

Crossett, K., B. Ache, P. Pacheco, and K. Haber. 2013. National Coastal Population Report Population Trends from 1970 to 2020. NOAA State of the Coast Report Series, US Department of Commerce, Washington, DC.

Davidson, L. M. 1992. Black Rail. In K. J. Schneider and D. M. Pence, editors. Migratory nongame birds of management concern in the Northeast (pp. 119-134). U.S. Fish and Wildlife Service Region 5. Newton Corner, MA.

eBird. 2018. eBird: An online database of bird distribution and abundance [online] URL:. eBird, Cornell Lab of Ornithology, Ithaca, New York. http://www.ebird.org

Gornitz, V. M., R. C. Daniels, T. W. White, and K. R. Birdwell. 1994. The development of a coastal risk assessment database: vulnerability to sea-level rise in the U.S. Southeast. Journal of Coastal Research, Special issue 12:327-338.

Hand, C. E., E. Znidersic, and A. K. Tegeler. 2019. First documentation of eastern Black Rails (Laterallus jamaicensis jamaicensis) breeding in South Carolina, USA in more than a century. Waterbirds 42(2):237-241. https://doi.org/10.1675/063.042.0212

Haverland, A. A. 2019. Determining the status and distribution of the eastern Black Rail (Laterallus jamaicensis) in coastal Texas. $\mathrm{PhD}$ dissertation, Texas State University. https://digital.library. txstate.edu/handle/10877/8330

Hedley, R. W., L. J. T. McLeod, D. A. Yip, D. Farr, P. Knaga, K. Drake, and E. Bayne. 2020. Modeling the occurrence of the Yellow Rail (Coturnicops noveboracensis) in the context of ongoing resource development in the oil sands region of Alberta. Avian Conservation and Ecology 15(1):10. https://doi.org/10.5751/ ACE-01538-150110

$\mathrm{Hu}$, J., and Y. Liu. 2014. Unveiling the conservation biogeography of a data-deficient endangered bird species under climate change. PLoS ONE 9(1):e84529. https://doi.org/10.1371/journal.pone.0084529

Jarnevich, C. S., T. R. Holcombe, B. A. Grisham, J. Timmer, C. W. Boal, M. Butler, J. Pitman, S. Kyle, D. Klute, G. Beauprez, A. Janus, and B. Van Pelt. 2016. Assessing range-wide habitat suitability for the Lesser Prairie-Chicken. Avian Conservation and Ecology 11(1):2. https://doi.org/10.5751/ACE-00807-110102

Jueterbock, A., I. Smolina, J. A. Coyer, and G. Hoarau. 2016. The fate of the Arctic seaweed Fucus distichus under climate change: an ecological niche modeling approach. Ecology and Evolution 6(6):1712-1724. https://doi.org/10.1002/ece3.2001 
Legare, M. L., and W. R. Eddleman. 2001. Home range size, nestsite selection and nesting success of Black Rails in Florida. Journal of Field Ornithology 72(1):170-177. https://doi. org/10.1648/0273-8570-72.1.170

Metzger, M. J., R. G. H. Bunce, R. H. G. Jongman, R. Sayre, A. Trabucco, and R. Zomer. 2013. A high-resolution bioclimate map of the world: a unifying framework for global biodiversity research and monitoring. Global Ecology and Biogeography 22:630-638. https://doi.org/10.1111/geb.12022

Moreno, R., R. Zamora, J. Ramón Molina, A. Vasquez, and M. Ángel Herrera. 2011. Predictive modeling of microhabitats for endemic birds in South Chilean temperate forests using Maximum entropy (MaxEnt). Ecological Informatics 6(6):364-370. https:// doi.org/10.1016/j.ecoinf.2011.07.003

Nadeau, C. P., and C. J. Conway. 2015. Optimizing water depth for wetland-dependent wildlife could increase wetland restoration success, water efficiency, and water security. Restoration Ecology 23(3):292-300. https://doi.org/10.1111/rec.12180

Nicholls, R. J. 2004. Coastal flooding and wetland loss in the 21st century: Changes under the SRES climate and socio-economic scenarios. Global Environmental Change 14:69-86. https://doi. org/10.1016/j.gloenvcha.2003.10.007

Nixon, A. E., R. J. Fisher, D. Stralberg, E. M. Bayne, and D. Farr. 2016. Projected responses of North American grassland songbirds to climate change and habitat availability at their northern range limits in Alberta, Canada. Avian Conservation and Ecology 11(2):2. http://dx.doi.org/10.5751/ACE-00866-110202

Palomino, D., J. Seoane, L. M. Carrascal, and C. L. Alonso. 2008. Competing effects of topographic, lithological, vegetation structure and human impact in the habitat preferences of the Cream-coloured Courser. Journal of Arid Environments 72 (4):401- 410. https://doi.org/10.1016/j.jaridenv.2007.07.007

Pearce, J. L., and M. S. Boyce. 2006. Modelling distribution and abundance with presence-only data. Journal of Applied Ecology 43(3):405-412. https://doi.org/10.1111/j.1365 2664.2005.01112.X

Phillips, S. J., R. P. Anderson, and R. E. Schapire. 2006. Maximum entropy modeling of species geographic distributions. Ecological Modelling 190:231-259. https://doi.org/10.1016/j.ecolmodel.2005.03.026

Phillips, S. J., M. Dudík, and R. E. Schapire. 2004. A maximum entropy approach to species distribution modeling. Twenty-First International Conference on Machine Learning ICML '04, 83. https://doi.org/10.1145/1015330.1015412

R Core Team. 2019. R: A language and environment for statistical computing. R Foundation for Statistical Computing, Vienna, Austria. URL https://www.R-project.org/.

Richmond, O. M., S. K. Chen, B. B. Risk, J. Tecklin, and S. R. Beissinger. 2010. California Black Rails depend on irrigation-fed wetlands in the Sierra Nevada foothills. California Agriculture 64 (2):85-93. https://doi.org/10.3733/ca.v064n02p85

Richmond, O. M., J. Tecklin, and S. R. Beissinger. 2008. Distribution of California Black Rails in the Sierra Nevada foothills. Journal of Field Ornithology 79(4):381-390. https://doi. org/10.1111/j.1557-9263.2008.00195.X
Roach, N. S., and K. Barrett. 2015. Managed habitats increase occupancy of Black Rails (Laterallus jamaicensis) and may buffer impacts from sea level rise. Wetlands 35(6):1065-1076. https://doi. org/10.1007/s13157-015-0695-6

Shamshuddin, J., M. Anda, C. I. Fauziah, and S. R. Syed Omar. 2011. Growth of cocoa planted on highly weathered soil as affected by application of basalt and/ or compost. Communications in Soil Science and Plant Analysis 42 (22):2751-2766. https://doi.org/10.1080/00103624.2011.622822

Spautz, H., N. Nur, and D. Stralberg. 2005. California Black Rail (Laterallus jamaicensis coturniculus) distribution and abundance in relation to habitat and landscape features in the San Francisco Bay estuary. USDA Forest Service General Technical Report PSW-GTR-191. http://www.treesearch.fs.fed.us/pubs/31463

Stuart, G. H. 1920. Nesting of the little Black Rail in Atlantic County, N. J. The Auk 37(2):292-293.

Taylor, B., and B. Van Perlo. 1998. Rails: A Guide to the Rails, Crakes, Gallinules and Coots of the World. Pica Press. Sussex, U. K.

Tolliver, J. D. M., A. M. Moore, M.C. Green, and F. W. Weckerly. 2018. Coastal Texas Black Rail population states and survey effort. Journal of Wildlife Management 83:312-324. https://doi. org/10.1002/jwmg.21589

Tsao, D. C., R. E. Melcer, Jr., and M. Bradbury. 2015. Distribution and habitat associations of California Black Rail (Laterallus jamaicensis cortuniculus) in the Sacramento-San Joaquin Delta. San Francisco Estuary and Watershed Science 13:4. http://dx.doi. org/10.15447/sfews.2015v13iss4art4

U.S. Fish and Wildlife Service. 2018a. Species status assessment report for the Eastern Black Rail (Laterallus jamaicensis jamaicensis), Version 1.2. June 2018. Atlanta, GA

U.S. Fish and Wildlife Service. 2018b. 12-month petition finding and threatened species status for Eastern Black Rail with a section 4(d) rule. Federal Register Agency Docket No. FWS-R4ES-2018-0057 pp. 50610-50630.

U.S. Fish and Wildlife Service. 2020. Endangered and Threatened Wildlife and Plants; Review of Domestic Species That Are Candidates for Listing as Endangered or Threatened; Annual Notification of Findings on Resubmitted Petitions; Annual Description of Progress on Listing Actions. Federal Register Agency Docket No. FWS-HQ-ES-2020-0003 pp. 73164-73179.

Walker, J., and P. D. Taylor. 2017. Using eBird data to model population change of migratory bird species. Avian Conservation and Ecology 12(1):4. https://doi.org/10.5751/ACE-00960-120104

Watts, B. D. 2016. Status and distribution of the Eastern Black Rail along the Atlantic and Gulf Coasts of North America. The Center for Conservation Biology Technical Report Series, CCBTR-16-09. College of William and Mary/Virginia Commonwealth University, Williamsburg, VA. 148 pp.

Wilson, M. D., B. D. Watts, and D. Brinker. 2007. Status review of Chesapeake Bay marsh lands and breeding marsh birds. Waterbirds 30:122-137. https://doi.org/10.1675/1524-4695(2007) 030[0122:SROCBM]2.0.CO;2 
Wilson, M. D., B. D. Watts, and D. Poulton. 2016. Black Rails in North Carolina. Center for Biology Technical Report Series, CCBTR-16-01, College of William and Mary and Virginia Commonwealth University, Williamsburg, VA.

Wu, T. Y., P. F. Lee, R. S. Lin, J. L.Wu, and B. A. Walther. 2012. Modeling the distribution of rare or cryptic bird species of Taiwan. Taiwania 57(4):342-358.

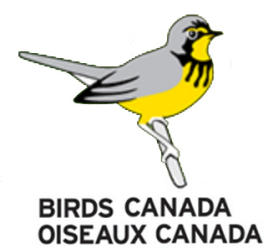

